\title{
Establishment of mature axillary bud culture of sugarcane and overcoming persistent culture contamination
}

M.E. Wagih ${ }^{A}$, S.W. Adkins ${ }^{B}$ and K. Attia ${ }^{C}$

${ }^{A}$ Department of Biology, Faculty of Science, University of New Brunswick, Saint John, NB, Canada.

${ }^{B}$ Department of Agriculture, The University of Queensland, Brisbane, QId 4072

${ }^{\mathrm{C}}$ Institute of Genetic Engineering, Fudan University, Shanghai, 200433, China

\section{wagih@unb.ca}

Abstract: Several methods to eradicate decontaminate sugarcane apical and lateral buds contaminants from sugarcane mature axillary budculture including bud location/age, surface sterilization and thermal and chemical treatments of buds are examined. A spectacular improvement in the decontamination rate to $95.8 \%$ was obtained when the heat treatment $61^{\circ} \mathrm{C}$ for $30 \mathrm{~min}$. was initially applied, followed by either 52 or $57^{\circ} \mathrm{C}$ for $30 \mathrm{~min}, 24$ hours apart. The various methods investigated and the successful rates of decontamination of sugarcane axillary buds may have a wider application in other plant tissue culture systems with known persistent contamination.

Keywords: axillary bud culture, tissue culture contamination, disease free stock, sugarcane Introduction

The establishment of an aseptic tissue culture method is an essential step before any attempt at further use of the culture is made. During tissue culture, pathogenic and non-pathogenic fungi and bacteria are revealed as contaminants and therefore can routinely be disposed off. Systemic viruses however, are much more difficult to eliminate (Roca, 1980). Like it is in many tissue culture systems, in sugarcane intensive persistent contamination has been frequently reported despite the use of strong surface sterilization treatments of explants used in tissue culture (Ahloowalia \& Meretzki, 1983; Wagih et al., 1995). This may occur due to the occurrence of indigenous microorganisms that are harbored within the explants tissues.

As contaminants vary in their media requirements, contamination is easily observed when the tissue culture media are themselves supportive for the growth of contaminants. However, if the objective is to regenerate diseasefree plants, contaminant, which requires specific media to grow, may require selective media to speed up the growth of such contaminants to a visible level (Dale, 1979; Lane, 1979; James \& Thurbon, 1981). Fastidious microorganisms, however, remain problematic, as they require very specific media to grow.

Different approaches to overcoming contamination in sugarcane tissue culture have been used with no successes. Hendre et al., (1975) used surface sterilization under vacuum to

( $0.4 \%$ chlorine for $20 \mathrm{~min}$ ). Moreover, despite heat treatment of sugarcane sets prior to bud excision and surface sterilization (1\% chlorine for $2 \mathrm{~min}$ ), cultures remained contaminated (Waterworth \& Kahn, 1978). Similar results were obtained by other workers who have grown donor plants in greenhouse to minimize the initial source of contamination (Heinz \& Mee, 1969, Krishnamurthi \& Tiaskal, 1974). Ahloowalia and Meretzki (1983) also failed to eradicate contaminants from sugarcane tissue culture. They dipped single nodesets in saturated Benlate solution, germinated sets in plastic boxes at 37 to $39^{\circ} \mathrm{C}$ and then soaked two weeks old shoots in $5.25 \% \mathrm{NaOCl}$ for $25 \mathrm{~min}$ followed by $95 \%$ ethanol for $1 \mathrm{~min}$ and rinsed twice in sterile distilled water.

Thermal and chemical treatments have also been used to eradicate contamination. While thermal treatments are difficult to use in decontaminating explants without damaging them, the use of chemotherapy (broad-spectrum fungicide and bactericides) has been useful (Johnson et al., 1982). Benomyl (Benlate), methyl1-butylcarbamoy P-2-benzimidazole carbamate (Erwin, 1973) and Nystatin (Mycostatin) (Beezer \& Sharma, 1981) are the most widely used broadspectrum fungicides in tissue culture. Unlike most fungi, yeast is relatively insensitive to Benlate (Hammerschalg \& Sisler, 1972). Nystatin however, is effective against yeast and is widely used to control contamination in tissue culture. Treatment of yeast cell suspension with $150 \mathrm{ml} \mathrm{L}^{-1}$ Nystatin for 12 hrs yielded only $4 \%$ yeast survivors when planted onto Nystatin free medium (Mousa, 1988). Similarly, several antibacterial antibiotics have also been used in tissue culture. Most commonly used antibiotic is Carbenicillin, a derivative of penicillin that belongs to "betalactam" antibiotic group, and is has been recommended to control gram-negative bacteria and showed very low phytotoxic effect on plant tissue culture (Pollock et al., 1983).

These anticontaminants alone or in combination with others have been used in decontaminating tissue cultures. For example, Johnson et al. (1982) included a combination of broad-spectrum bactericides and fungicides in the culture media of Halics phalaenopsis flower stalk node cultures and found that the initial explants did not require sterilization. They use the bactericide Penicillin G 
(100 ml L'-1) in $70 \%$ aqueous ethanol and Gentamycin $\left(50 \mathrm{ml} \mathrm{L}^{-1}\right)$ in sterile liquid together with fungicide, Benlate $\left(50 \mathrm{ml} \mathrm{L}^{-1}\right)$ in water and Nystatin $\left(25 \mathrm{ml} \mathrm{L}^{-1}\right)$ in absolute ethanol. Moreover, extensive contamination in apical meristem culture of sugarcane has been controlled with a combination of tetracycline and aureofungin (Hendre et al., 1975).

There is considerable evidence that high temperature limits growth or kills microorganisms. Growth is controlled at least in part by the thermo ability of their enzymes and enzyme forming systems (Strokes, 1967). Yeast cells, for example, are usually killed by exposure to temperature in the range of $50-60{ }^{\circ} \mathrm{C}$ for less than $30 \mathrm{~min}$. Recently, a novel thermotherapy technique was developed to eradicate indigenous contaminants from sugarcane Axillary bud-culture prior to culturing (Wagih et al., 1995). The culture was successfully established with the aid of a double heat treatment applied firstly to sets $\left(50{ }^{\circ} \mathrm{C}\right.$ for $\left.120 \mathrm{~min}\right)$ and then to the isolated Axillary buds $\left(61^{\circ} \mathrm{C}\right.$ for $\left.30 \mathrm{~min}\right)$.

This paper summarizes our experiences with difficult-to-eradicate contaminants in sugarcane mature axillary bud-culture, which offers an example of systematic investigation and eradication of contaminants from tissue culture systems in general.

Materials and methods

Donor Plants

First ratoon of three commercial cv. of Saccharum officinarum; NC0310, Q87 \& CP44-101 Preharvest preparation of donor plants

Sugarcane plants 4-6 months-old were stripped of all the lower leaves, 3-5 days prior to harvesting. The stripped cane was decapitated and sprayed with the broad-spectrum fungicide Benlate at concentration of $0.6 \mathrm{~g} \mathrm{~L}^{-1}$ (50\% Benomyl) and the insecticide Metasystox at concentration of $1 \mathrm{ml} \mathrm{L}^{-1}$. Sets wash and thermal treatments

One eye sets $(3-4 \mathrm{~cm})$ of freshly cut sugarcane stems were put into a mesh basket and soaked and washed for $5 \mathrm{~min}$ in a bath of warm tap water containing $5 \%$ of the detergent "Decon", rinsed with tap running water, drained, and covered with a moist paper towels if not immediately processed.

Washed sets were given a hot water treatment in a "Thermomix" water bath. This apparatus was modified with a glass lid and two thermometers, one in the rear and the other in the front of the bath to ensure an even water temperature throughout the bath. Maximums of 30 sets were treated at any one time in order to fully expose each of the sets to the heat treatment.

\section{Dissection and surface sterilization of buds}

Buds were excised from mature small sets or stalk pieces by holding sets resting on a steady surface and cutting with a scalpel blade (No. 11) 5 $\mathrm{mm}$ deep behind and along the base of the buds. The scalpel was returned to the starting point of incision and a second cut was made in a slow arc around and beneath the bud. The bud was then detached. The scalpel blade was sterilized in Zephiran solution made in $10 \%$ ethanol before the excision of each bud. Buds with apparent damage or dark browning were eliminated at this stage. One of three scales was then removed from the excised buds, which were used as explants.

In the initial cultures, buds were surface sterilized by three different methods involving: (A) rinsing buds in $70 \%$ ethanol for $1 \mathrm{~min}$ in $1 \%$ Zephiran for $10 \mathrm{~min}$, then in $70 \%$ filtered ethanol for $1 \mathrm{~min}$ and finally washed buds in distilled sterile water (3 times); (B) rinsing buds in $70 \%$ ethanol for 30 seconds, $1 \%$ chlorine (sodium hypochlorite) for $15 \mathrm{~min}$, and finally washing buds in distilled sterile water 3 times or (C) rinsing buds in $5 \%$ chlorine (sodium hypochlorite) containing Tween 20 (a drop per $100 \mathrm{~m} \mathrm{~L}$ solution) for $5 \mathrm{~min}, 70 \%$ ethanol for $1 \mathrm{~min}$, and finally washing buds in distilled sterile water (3 times).

\section{Bud-thermal treatment}

Sterilized "Coster" tissue culture clusters $(4 \times 6$ wells) were used for the thermal treatment of the surface sterilized sugarcane buds. Under aseptic conditions, plates were charged by placing individual buds into individual wells containing $2 \mathrm{ml}$ of a modified liquid MS medium (Murashige \& Skoog, 1962).

This medium contains the fungicide Benomyl (100 ppm) and Nystatin (25 ppm) and the bactericide Carbenicillin (100 ppm). The charged plates were then wrapped with parafilm and placed in a plastic box and in a thermomix water bath set at the required temperature and covered with a glass lid. A maximum of one plate was heat-treated at any one time.

Determination of the least effective concentration of anticontaminants

The least effective concentration (LEC) of 5 fungicides, Benomyl, Actidione, Captan, Fenbendazole and Nystatin, and the bactericide Carbenicillin, was determined by spreading culturecontaminating agents (Fungal mycelia, yeast and bacteria) onto MS agar in Petri dishes containing a range of concentration of these anticontaminants. The LEC was considered as the lowest concentration, which gave no visible growth of contaminants.

\section{Bud cultures and experimental procedures}

These procedures were essential as described by Wagih et al. (1995). Shoots initiated by placing the Axillary buds onto a standard bud culture medium containing 1/2 MS nutrient and organics, 8 
Table 1. Decontamination of bud cultures of FDV-infected fieldgrown sugarcane, cv. NCo310 using different surface sterilization methods. Each treatment involved 20 buds.

\begin{tabular}{|c|c|c|c|c|c|}
\hline \multicolumn{3}{|c|}{ Surface Sterlization Methods ${ }^{*}$} & \multicolumn{3}{|c|}{ Culture Condition after 3 Days Inc ubation } \\
\hline $\begin{array}{c}\text { Treatment } \\
\text { No. }\end{array}$ & $\underset{\%}{\text { Chlorine }}$ & $\begin{array}{c}\text { Treatment } \\
\text { Period } \\
\text { (min) }\end{array}$ & $\begin{array}{c}\text { Conta'ed } \\
(\%)\end{array}$ & $\begin{array}{c}\text { Deconta'ed } \\
(\%)\end{array}$ & $\begin{array}{r}\text { Dead } \\
(\%)\end{array}$ \\
\hline 1 & 1 & $15+$ & 90 & 0 & 10 \\
\hline 2 & & $20+$ & 75 & 15 & 10 \\
\hline 3 & & $30+$ & 40 & 20 & 40 \\
\hline 4 & 2 & $10+$ & 75 & 10 & 15 \\
\hline 5 & & $15+$ & 50 & 20 & 30 \\
\hline 6 & & $20+$ & 25 & 30 & 45 \\
\hline 7 & & $30+$ & 20 & 20 & 60 \\
\hline 8 & & 30 & 15 & 30 & 55 \\
\hline 9 & 3 & $10+$ & 45 & 20 & 35 \\
\hline 10 & & $15+$ & 15 & 15 & 70 \\
\hline 11 & & $20+$ & 40 & 30 & 30 \\
\hline 12 & 4 & $5+$ & 40 & 25 & 35 \\
\hline 13 & & $10+$ & 5 & 30 & 65 \\
\hline 14 & & 5 & 55 & 40 & 5 \\
\hline 15 & & 6 & 60 & 20 & 20 \\
\hline 16 & & 7 & 65 & 15 & 20 \\
\hline 17 & & 10 & 35 & 30 & 35 \\
\hline
\end{tabular}

${ }^{*}$ In all trea tments buds were first rinsed in $70 \%$ alcohol ethanol for $1 \mathrm{~min}$.

$+\mathrm{B}$ ud $s$ w ere further rinsed in filtered $70 \%$ ethanol for $1 \mathrm{~min}$.

Table 2. Determination of the Least Effective Concentration (LEC) of several decontaminating agents on a mix of contaminants isolated from bud-cultures of FDV-infected field-grown sugarcane cv. NCo310.

\begin{tabular}{|c|c|c|c|c|c|c|c|c|c|}
\hline Fungic ides & $\begin{array}{c}\text { 1. Benomyl (pp m) } \\
\text { Mycelia * } \\
\text { Yeast } \\
\text { B acteria }\end{array}$ & $\begin{array}{cc}0 & 2 \\
+++ & + \\
+++ & ++ \\
+++ & ++\end{array}$ & $\begin{array}{l}25 \\
++ \\
++ \\
++ \\
++\end{array}$ & $\begin{array}{c}50 \\
- \\
+++ \\
+++\end{array}$ & $\begin{array}{c}100 \\
- \\
++ \\
+++\end{array}$ & $\begin{array}{l}200 \\
- \\
++ \\
+++\end{array}$ & $\begin{array}{c}300 \\
- \\
++ \\
+++\end{array}$ & $\begin{array}{c}400 \\
- \\
+ \\
++\end{array}$ & $\begin{array}{c}500 \\
- \\
- \\
+++\end{array}$ \\
\hline & $\begin{array}{l}\text { 2. Actiodione (ppm) } \\
\text { Mycelia } \\
\text { Yeast } \\
\text { B acteria }\end{array}$ & $\begin{array}{cc}0 & 1 \\
+++ & \\
+++ & + \\
+++ & +\end{array}$ & $\begin{array}{c}1.0 \\
+ \\
++ \\
+++\end{array}$ & $\begin{array}{c}2.0 \\
- \\
++ \\
+++\end{array}$ & $\begin{array}{c}3.0 \\
- \\
+ \\
+++\end{array}$ & $\begin{array}{c}4.0 \\
- \\
+ \\
+++\end{array}$ & $\begin{array}{c}5.0 \\
- \\
- \\
+++\end{array}$ & & \\
\hline & $\begin{array}{c}\text { 3. Captan (pp m) } \\
\text { M ycelia } \\
\text { Yeast } \\
\text { B acteria }\end{array}$ & $\begin{array}{cc}0 & 2 \\
+++ & + \\
+++ & ++ \\
+++ & ++\end{array}$ & $\begin{array}{l}25 \\
++ \\
+++ \\
+++\end{array}$ & $\begin{array}{c}50 \\
+ \\
+++ \\
+++\end{array}$ & $\begin{array}{c}100 \\
- \\
++ \\
+++\end{array}$ & $\begin{array}{c}150 \\
- \\
+ \\
+++\end{array}$ & $\begin{array}{c}200 \\
- \\
+ \\
+++\end{array}$ & $\begin{array}{c}300 \\
- \\
- \\
+++\end{array}$ & $\begin{array}{l}400 \\
- \\
- \\
+++\end{array}$ \\
\hline & $\begin{array}{l}\text { 4. Fenbendazole (p m) } \\
\text { M ycelia } \\
\text { Yeast } \\
\text { B acteria }\end{array}$ & $\begin{array}{ll}0 & \\
+++ & + \\
+++ & ++ \\
+++ & ++\end{array}$ & $\begin{array}{c}25 \\
+++ \\
+++ \\
+++\end{array}$ & $\begin{array}{c}50 \\
++ \\
+++ \\
+++\end{array}$ & $\begin{array}{c}100 \\
- \\
++ \\
+++\end{array}$ & $\begin{array}{c}150 \\
- \\
+ \\
+++\end{array}$ & $\begin{array}{c}200 \\
- \\
+ \\
+++\end{array}$ & $\begin{array}{c}300 \\
- \\
+ \\
+++\end{array}$ & $\begin{array}{c}400 \\
- \\
- \\
+++\end{array}$ \\
\hline & $\begin{array}{c}\text { 5. Nystatin (ppm) } \\
\text { M ycelia } \\
\text { Yeast } \\
\text { B acteria }\end{array}$ & $\begin{array}{cc}0 & 2 \\
+++ & + \\
+++ & ++ \\
+++ & ++\end{array}$ & $\begin{array}{l}25 \\
+++ \\
+++ \\
+++\end{array}$ & $\begin{array}{l}50 \\
++ \\
++ \\
+++\end{array}$ & $\begin{array}{c}100 \\
- \\
++ \\
+++\end{array}$ & $\begin{array}{c}150 \\
- \\
+ \\
++\end{array}$ & $\begin{array}{c}200 \\
- \\
+ \\
+++\end{array}$ & $\begin{array}{c}300 \\
- \\
- \\
+++\end{array}$ & $\begin{array}{c}400 \\
- \\
- \\
+++\end{array}$ \\
\hline $\begin{array}{l}\text { Bacteric ide } \\
\text { with the fung }\end{array}$ & $\begin{array}{r}\text { 6. Carbenicillin (p pm) } \\
\text { icide Benomyl (pp m) } \\
\text { M ycelia } \\
\text { Yeast } \\
\text { Bacteria }\end{array}$ & $\begin{array}{c}0 \\
500 \\
- \\
- \\
+++\end{array}$ & $\begin{array}{c}40 \\
500 \\
- \\
- \\
+++\end{array}$ & $\begin{array}{c}60 \\
500 \\
- \\
- \\
+\quad+\end{array}$ & $\begin{array}{c}80 \\
500 \\
- \\
- \\
+\end{array}$ & $\begin{array}{c}90 \\
500 \\
- \\
- \\
+\end{array}$ & $\begin{array}{c}100 \\
500 \\
- \\
- \\
-\end{array}$ & $\begin{array}{c}110 \\
500 \\
- \\
- \\
-\end{array}$ & \\
\hline
\end{tabular}

* $(-)$ no grow th; light $(+)$ medium $(++)$ and abundant $(+++)$ of contaminating agent g L $\mathrm{L}^{-1}$ agar (Bacto-Agar, Difico Products, Qld. Australia), $3 \mathrm{mg} \mathrm{L}^{-1} \mathrm{NAA}, 500 \mathrm{mg} \mathrm{L}^{-1}$ malt extract with 30 or $60 \mathrm{~g} \mathrm{~L}^{-1}$ sucrose (Waterworth and Kahn, 1978). In addition, the media contained $250 \mathrm{mg} \mathrm{L}^{-1}$ diethyldithiocarbamic acid (DEDC) to reduce tissue browning due to phenolic release. Roots were induced onto the same medium with $2 \mathrm{ml} \mathrm{L}^{-1}$ http://www.indjst.org Vol.2 No 1 (Jan. 2009)
Naphthylacetic acid (NAA) or $1 \mathrm{ml}$ $\mathrm{L}^{-1}$ Indole butyric acid (IBA) and 30 to $60 \mathrm{~g} \mathrm{~L}^{-1}$ sucrose, or in distilled sterile water which was changed daily. The bud culture vessels were incubated at $28 \pm 2{ }^{\circ} \mathrm{C}$ for a photoperiod of $16 \mathrm{hrs}\left(150 \mu \mathrm{mol} \mathrm{m}^{-}\right.$ $\left.2 \mathrm{~s}^{-1}\right)$. Plantlet with about $10 \mathrm{~cm}$ long shoots were transferred to autoclaved potting compost and grown under high humidity. Plantlets were watered weekly and finally transferred to $20 \mathrm{~cm}$ pots and maintained to maturity.

Statistical analysis

Each experiment included at least 24 buds or more, and repeated at least twice with similar results. Analyses of variance and test significance of differences among treatment means of decontaminated buds were done using SAS program.

Results and discussions

Survival of contaminants following surface sterilization

Initial surface sterilization of axillary buds from the three varieties NCo 310, CP44-101 and Q87 was done using three methods as shown in the materials and methods section. During the first three days of culture, the nonsurface sterilized buds of all varieties, aseptically excised from greenhouse or field grown plants, became $100 \%$ contaminated. The contaminating agents include fungi (mainly Ceratocystis paradoxa), yeast and bacteria. The level of contamination produced on buds from the field grown sugarcane was more extensive than that on buds from plants grown in the greenhouse. The treatment involving rinsing buds for $5 \mathrm{~min}$ in $5 \%$ chlorine followed by $1 \mathrm{~min}$ in $70 \%$ ethanol was found to decontaminate the highest percentage of buds of NCo 310 , CP44-101 and Q87 from the field-grown plants; scoring 77, 67 and $73 \%$, respectively. However, The percentage of contaminated cultures cultivars increased over the incubation period. At ten days in culture, all buds that were apparently decontaminated by surface sterilization developed contamination, mainly with yeast originating from 
the base of the buds and spreading into the culture media forming a typical white cloud. The existence of similar yeast contamination in the sugarcane tissue culture from either greenhouse or field grown sugarcane plants has been previously reported (Irvine \& Benda, 1987).

\section{Origin of contaminants in explants}

To verify the delay and pattern of contamination development with the assumption that the contaminating agents are deep-seated and are subsequently released through the base of the buds into the culture media, 10 buds from the field-grown NCo310 sugarcane cultivar were surface sterilized and cultured on MS agar media. After three days of culture, six apparently clean buds were aseptically removed from the culture and two buds scales were carefully peeled off from each bud. The remaining cores were aseptically macerated and shaken in $20 \mathrm{ml}$ of YEPG broth overnight at $37{ }^{\circ} \mathrm{C}$. After this treatment, the broth, which appeared cloudy, was diluted and plated out onto YEPG agar in Petri plates and incubated at $37^{\circ} \mathrm{C}$ for 48 hours. The plates were found to be covered with a large number of yeast colonies and to a lesser extend with bacterial colonies and white fungal mycelia. These mycelia were identified as Ceratocysis paradoxa, the causal agent for pineapple disease of sugarcane. These observations confirm the assumption that good proportions of the bud contaminants are deep seated in the bud tissue as well as on the surface of the bud scales. The persistence of contamination in bud cultures due to endogenous microorganisms that are harbored within the explants tissue has been previously reported (Dale, 1979; Lane, 1979; James \& Thurbon, 1981).

Based on this result, the application of 17 different surface sterilization treatments on buds of NCo 310 (Table 1) showed that the highest decontamination rate and least harm was achieved by treatment number 14 involving rinsing buds for $1 \mathrm{~min}$ in $70 \%$ ethanol followed by $5 \mathrm{~min}$ in chlorine. The other treatments, however, were either too aggressive or too weak.

Effect of bud location on decontamination rate

Significant improvement in decontaminating buds was achieved by culturing young buds taken from the upper half of the sugarcane stem, versus older buds taken from the lower half of the stem. After 3 days of culture, the young buds gave rise to approximately $40 \%$ clean cultures against approximately $13 \%$ of the older buds (Fig. 1). After 10 days of incubation $30 \%$ of the young buds remained clean while all of the older buds became contaminated, mainly with yeast. However, the survival rate of younger buds after prolong
Fig. 1. Bud cultures from the field-grown sugarcane cultivars NCo 310: Effect of bud position on the percentage yield of decontaminated, contaminated and dead. Young buds were of the upper half of the stalk, whereas old buds were of the lower half. Each treatment was presented bv 60 buds.

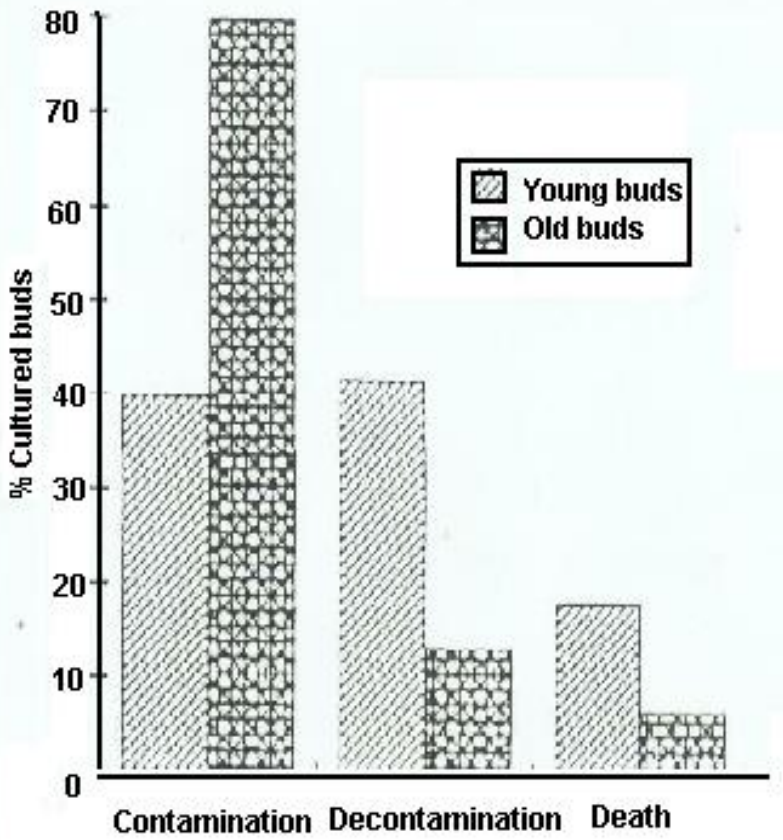

Fig. 2. Determination of the Thermal Death Point (TDP) of the yeast contaminant when heat treated at various temperatures in a suspension medium of half strength MS, pH 5.3.

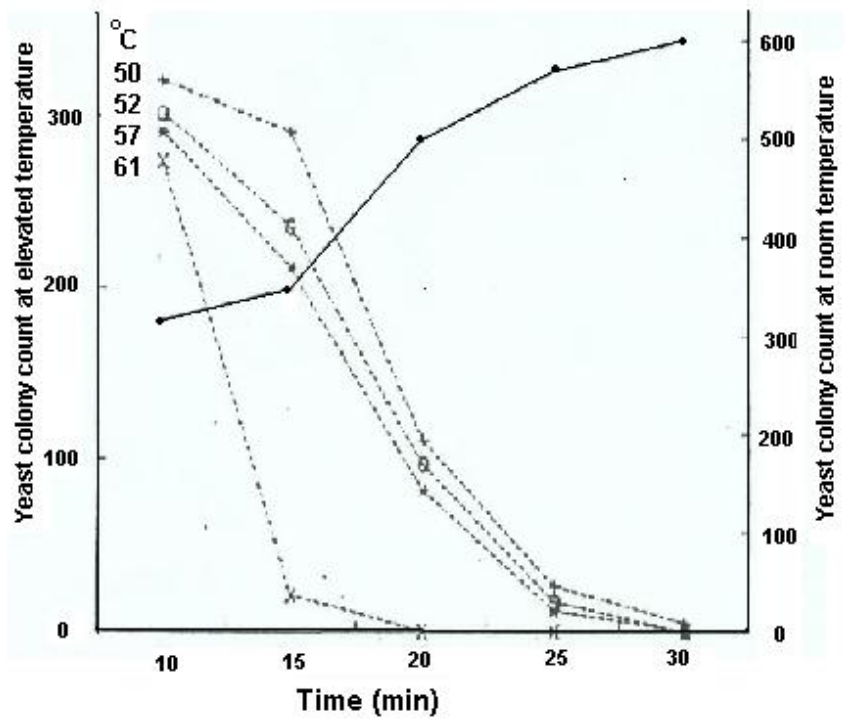

incubation was significantly $(p<0.05)$ reduced. Moreover, despite that young buds are likely to produce contamination-free cultures, older buds are more likely to survive in cultures and are able to overcome subsequent decontamination 
Table 3. Effect of the fungicides Benomyl and Nystatin on controlling yeast contamination in bud-culture of field-grown DFVinfected sugarcane, cv. NCo310. Culture media contained the bactericide Carbenicillin (100 ppm) and each treatment involved 30 buds.

\begin{tabular}{|c|c|c|c|c|c|}
\hline \multirow[b]{2}{*}{ Treatment } & \multirow[b]{2}{*}{$(\mathrm{ppm})$} & \multicolumn{3}{|c|}{ Condition of bud culture (10 days) } & \multirow{2}{*}{$\begin{array}{l}\text { Major } \\
\text { contaminants } \\
+ \text { remaining }\end{array}$} \\
\hline & & $\begin{array}{c}\text { Contam ed } \\
(\%)\end{array}$ & $\begin{array}{c}\text { Decontam ed } \\
(\%)\end{array}$ & $\begin{array}{r}\text { Dead } \\
(\%)\end{array}$ & \\
\hline $\begin{array}{l}\text { Control } \\
\text { Benomyl }\end{array}$ & $\begin{array}{c}0 \\
500^{*} \\
400 \\
300 \\
200 \\
100 \\
50\end{array}$ & $\begin{array}{l}96.7 \\
36.7 \\
36.7 \\
43.3 \\
43.3 \\
53.3 \\
76.7\end{array}$ & $\begin{array}{c}0 \\
23.3 \\
16.7 \\
20.0 \\
20.0 \\
13.3 \\
10.0\end{array}$ & $\begin{array}{c}3.3 \\
40.0 \\
40.0 \\
36.7 \\
26.7 \\
10.0 \\
6.7\end{array}$ & $\begin{array}{l}\mathrm{Y}+\mathrm{F}+\mathrm{B} \\
\mathrm{Y} \\
\mathrm{Y} \\
\mathrm{Y} \\
\mathrm{Y} \\
\mathrm{Y} \\
\mathrm{Y}+\mathrm{F}\end{array}$ \\
\hline $\begin{array}{l}\text { Control } \\
\text { Nystatin }\end{array}$ & $\begin{array}{c}0 \\
300^{*} \\
250 \\
200 \\
150 \\
100 \\
50 \\
25\end{array}$ & $\begin{array}{l}93.3 \\
30.0 \\
43.3 \\
50.0 \\
53.3 \\
60.0 \\
76.7 \\
86.7\end{array}$ & $\begin{array}{l}0 \\
26.7 \\
20.0 \\
20.0 \\
16.7 \\
20.0 \\
13.3 \\
10.0\end{array}$ & $\begin{array}{l}6.7 \\
43.3 \\
36.7 \\
30.0 \\
30.0 \\
20.0 \\
10.0 \\
3.3\end{array}$ & $\begin{array}{l}\mathrm{Y}+\mathrm{F}+\mathrm{B} \\
\mathrm{Y} \\
\mathrm{Y} \\
\mathrm{Y} \\
\mathrm{Y}+\mathrm{F} \\
\mathrm{Y} \\
\mathrm{Y}+\mathrm{F} \\
\mathrm{Y}+\mathrm{F}\end{array}$ \\
\hline
\end{tabular}

* Least E ffective Concentration for this fungic id e (see $T$ ab le 2)

$+\mathrm{Y}=$ Yeast, $\mathrm{F}=\mathrm{Fungal}$ mycelia; $\mathrm{B}=$ bacteria

Table 4. Effect of pre-harvest preparation on subsequent decontamination rate of bud-culture of field-grown FDV-infected sugarcane, cv. NCo310. Each treatment involved 30 buds.

\begin{tabular}{|c|c|c|c|}
\hline \multirow[b]{2}{*}{ Methods } & \multicolumn{3}{|c|}{ Condition of bud-c ulture (10 days) } \\
\hline & $\begin{array}{c}\text { Contam 'ed } \\
(\%)\end{array}$ & $\begin{array}{c}\text { Decontam'ed } \\
(\%)\end{array}$ & $\begin{array}{r}\text { Dead } \\
(\%)\end{array}$ \\
\hline Control & 66.7 & 26.7 & 6.7 \\
\hline Stripped & 63.3 & 36.7 & 3.3 \\
\hline Stripped \& Sp rayed & 46.7 & 50.0 & 3.3 \\
\hline Stripped \& Decap itated & 53.3 & 46.7 & 0.0 \\
\hline Stripped, Decap itated and Sp rayed & 43.3 & 53.3 & 3.3 \\
\hline
\end{tabular}

Table 5. Determination of the "Thermal Death Point" (TDT) of the yeast contaminant, heat treated for 30 minutes in a suspension of yeast cultures made in Full Strength or Half

Strength (HS) MS media at various $\mathrm{pH}$ levels. Treated suspensions were placed on to Petri dishes on YEPG-agar medium and incubated at $37^{\circ} \mathrm{C}$ for $48 \mathrm{hrs}$.

\begin{tabular}{lcccc}
\hline & \multicolumn{5}{c}{ Mean Colony in 3 Petri dishes } \\
\cline { 2 - 5 } Thermal & FS & F S & HS & HS \\
Temperature & $(\mathrm{pH} 5.8)$ & $(\mathrm{pH} 5.3)$ & $(\mathrm{pH} 5.8)$ & $(\mathrm{pH} 5.3)$ \\
(9C) & 501 & 609 & 589 & 566 \\
\hline Control (23) & 561 & 579 & 593 & 589 \\
37 & 26 & 28 & 28 & 20 \\
50 & 6 & 6 & 6 & 0 \\
52 & 0 & 0 & 0 & 0 \\
55 & 0 & 0 & 0 & 0 \\
57 & 0 & 0 & 0 & 0 \\
61 & & & &
\end{tabular}

treatments that may be aimed at virus elimination (Wagih et al., 1995). http://www.indjst.org Vol.2 No 1 (Jan. 2009)

Effect of anticontaminants on isolated cultures of contaminants

The least effective concentration (LEC) of five fungicides and a bactericide on contaminants isolated from sugarcane bud cultures was determined (Table 2). The tested fungicides controlled fungal mycelia growth at LEC's lower than those of yeast. The LEC's, against fungal mycelia and against yeast, were respectively as follows: Benomyl 50 and $500 \mathrm{ppm}$, Actidione 2 and 5 ppm, Captan 100 and 300 ppm; Fenbendazole 100 and $400 \mathrm{ppm}$ and Nystatin 100 and 300 ppm. No fungicides, at any of the concentrated tested, were able to reduce bacterial growth. The bactericide, Carbenicillin, showed a LEC against the bacterial contaminants at $100 \mathrm{ppm}$ (in the presence of $500 \mathrm{ppm}$ of Benomyl to control fungal and yeast growth).

The decontaminating effect of the fungicides at their LEC's rates was further studied by combining each with the bactericide Carbenicillin, and placing them into culture media (Wagih et al., 1995). Different combinations of these decontaminating agents caused severe phytotoxic effects, resulting in $33.3 \%$ to $100 \%$ deaths of the cultures. A similar phytotoxicity was observed when the fungicides were applied in the absence of Carbenicillin. Carbenicillin alone did not result in an increase in the death rate above the control. The application of lower concentrations of Benomyl and Nystatin significantly $(p<0.05)$ reduced the phytotoxic effect of the fungicides. The bud death rate caused by Benomyl at 100 and $50 \mathrm{ppm}$ were $10.5 \%$ and $6.7 \%$ respectively, and caused by Nystatin at concentrations of 50 to $25 \mathrm{ppm}$ were $10 \%$ and $3.3 \%$. However, the percentage of the contaminated cultures produced by these treatments was very low.

Aiming to improve the yield of decontaminated bud cultures with the least possible phytotoxic effect, combination of different combination of the least phytotoxic antifungal chemicals Benomyl and Nystatin were 
tried (Table 3). When Benomyl (100 ppm) together with Nystatin $(25 \mathrm{ppm})$ were used, the death rate was reduced $(3.3 \%)$ to the control level, and the percentage production of clean cultures was significantly improved (30 \%). Therefore, this combination was selected together with $100 \mathrm{ppm}$ Carbenicillin to be used in further experiments.

Effect of pre-harvest preparation on decontamination of bud cultures

In addition to developing suitable surface sterilization techniques and the use of anticontaminants in the culture media, different Preharvest preparation methods of sugarcane donor plants were tested in subsequent bud decontamination rate. Stripping leaves from fieldgrown plant cv. NCo310 resulted in an improvement in the decontamination rate of bud cultures compared to unstripped control (Table 4). Additional $10 \%$ improvement was achieved by stripping and decapitating, spraying stripped plant with Benomyl and Metasytox further improved the rate of decontamination by $3.3 \%$. This combined chemical treatment was most effective when used on stripped and decapitated plants producing $53.3 \%$ totally clean cultures and $43 \%$ contaminated cultures, only by yeast.

The use of thermal treatments Determination of yeast thermal death point (TDP): Yeast cells isolated from old bud-cultures were suspended in 4 different liquid media and exposed to various elevated temperatures for $30 \mathrm{~min}$. Media differed in strength and $\mathrm{pH}$ value. Survivor counts showed that the thermal death temperature (TDT: the lowest temperature at which no yeast growth was observed) was $52{ }^{\circ} \mathrm{C}$ when the yeast cells were suspended in either full strength FS-MS medium, $\mathrm{pH} 5.3$ and 5.8 or in HS-MS medium, $\mathrm{pH}$ 5.8. When media differed only in $\mathrm{pH}$ value, the lower $\mathrm{pH}$ (5.3) reduced the survival rate the most. The strength of the media however, did not affect the survival rate.

The thermal death point (TDP= temperature \% time of exposure to elevated temperature at which no growth was observed) for yeast cells suspended in HS-MS medium, pH 5.3 (Fig. 2) were $52^{\circ} \mathrm{C}$ for $30 \mathrm{~min}$ treatment or $61^{\circ} \mathrm{C}$ for a
$20 \mathrm{~min}$ treatment. Exposure to $50{ }^{\circ} \mathrm{C}$ for $30 \mathrm{~min}$ greatly minimized the survival rate, but did not totally inhibit the growth. These TDP values were used to determine the effect of heat treatments on bud-culture in subsequent studies.

Effect of thermal treatments on buds. Single heat treatment of buds in HS-MS medium $(\mathrm{pH} \mathrm{5.3)} \mathrm{to}$ 50,52 or $57{ }^{\circ} \mathrm{C}$ for $30 \mathrm{~min}$, and $61^{\circ} \mathrm{C}$ for $20 \mathrm{~min}$ (Wagih and Adkins, 1995) showed that 50 and 52 ${ }^{\circ} \mathrm{C}$ produced high contamination of contaminated buds similar to that of the control. This was unlike 57 and $61^{\circ} \mathrm{C}$, which resulted in significant $(p<0.05)$ reduction in the contamination rate. However, the death rate was significantly $(p<0.05)$ increased. When buds were heat treated for 60,90 and 120 min at 52,57 or $61^{\circ} \mathrm{C}$, treatments at $52^{\circ} \mathrm{C}$ caused a gradual decrease in decontamination rate with a gradual increase in the bus death rate from $12.5 \%$ to $41.7 \%$. Heating buds to $57{ }^{\circ} \mathrm{C}$ for 60,90 and $120 \mathrm{~min}$ caused a severe decline in the decontamination rate and an increase in the death

Table 6. The effect of single thermal treatments on decontaminating bud-culture of field-grown FDV-infected sugarcane cv. NCo310. Each treatment involved 24 buds.

\begin{tabular}{|c|c|c|c|c|}
\hline \multicolumn{2}{|c|}{ Thermal Treatments } & \multicolumn{3}{|c|}{ Condition of bud -culture (10 days) } \\
\hline${ }^{\circ} \mathrm{C}$ & $\min$ & $\begin{array}{c}\text { Contam'ed } \\
(\%)\end{array}$ & $\begin{array}{c}\text { Deontam 'ed } \\
(\%)\end{array}$ & $\begin{array}{r}\text { Dead } \\
(\%)\end{array}$ \\
\hline $\begin{array}{l}\text { Control (23) } \\
50 \\
52 \\
57 \\
61\end{array}$ & $\begin{array}{r}0 \\
30 \\
30 \\
30 \\
20\end{array}$ & $\begin{array}{l}54.2 \\
50.0 \\
45.8 \\
25.0 \\
33.3\end{array}$ & $\begin{array}{l}41.7 \\
50.0 \\
50.0 \\
58.3 \\
50.0\end{array}$ & $\begin{array}{r}4.2 \\
0 \\
4.2 \\
16.7 \\
16.7\end{array}$ \\
\hline $\begin{array}{l}\text { Control }(23) \\
52 \\
52 \\
52\end{array}$ & $\begin{array}{l}0 \\
60 \\
90 \\
120\end{array}$ & $\begin{array}{l}54.2 \\
45.8 \\
33.3 \\
29.2\end{array}$ & $\begin{array}{l}37.5 \\
41.7 \\
41.7 \\
29.2\end{array}$ & $\begin{array}{r}8.3 \\
12.5 \\
25.0 \\
41.7\end{array}$ \\
\hline $\begin{array}{l}57 \\
57 \\
57\end{array}$ & $\begin{array}{l}60 \\
90 \\
120\end{array}$ & $\begin{array}{l}20.8 \\
12.5 \\
0.0\end{array}$ & $\begin{array}{r}33.3 \\
20.8 \\
0.0\end{array}$ & $\begin{array}{r}45.8 \\
66.7 \\
100.0\end{array}$ \\
\hline $\begin{array}{l}61 \\
61\end{array}$ & $\begin{array}{l}25 \\
30\end{array}$ & $\begin{array}{l}25.0 \\
20.8\end{array}$ & $\begin{array}{l}54.2 \\
58.3\end{array}$ & $\begin{array}{l}20.8 \\
20.8\end{array}$ \\
\hline
\end{tabular}

Table 7. Effect of two thermal treatments on decontaminating budculture of FDV-infected sugarcane cv. NCo310. Each treatment involved 24 buds.

\begin{tabular}{|c|c|c|c|c|c|c|c|}
\hline \multicolumn{5}{|c|}{ Thermal Treatments } & \multicolumn{3}{|c|}{ Conditions of bud-culture (10 days) } \\
\hline \multirow{2}{*}{\multicolumn{2}{|c|}{$\frac{1^{\text {st }} \text { Treatment }}{{ }^{\circ} \mathrm{C} \quad \mathrm{min}}$}} & \multirow{2}{*}{$\begin{array}{l}\text { Delay } \\
\text { hrs }\end{array}$} & \multicolumn{2}{|c|}{$2^{\text {nid }}$ Treatment. } & \multirow{2}{*}{$\begin{array}{c}\text { Contam'ed } \\
\left(0_{0}^{\circ}\right)\end{array}$} & \multirow{2}{*}{$\underset{(\%)}{\text { Decontam 'ed }}$} & \multirow{2}{*}{$\begin{array}{r}\text { Dead } \\
(\%)\end{array}$} \\
\hline & & & ${ }^{\circ} \mathrm{C}$ & $\min$ & & & \\
\hline 61 & 30 & - & - & - & 10.4 & 66.7 & 22.9 \\
\hline 61 & 30 & 24 & 52 & 30 & 29.2 & 35.4 & 35.4 \\
\hline 52 & 30 & 24 & 61 & 30 & 68.8 & 14.6 & 16.6 \\
\hline 61 & 30 & 24 & 57 & 30 & 25.0 & 20.8 & 54.2 \\
\hline 57 & 30 & 24 & 61 & 30 & 54.2 & 6.2 & 39.6 \\
\hline 61 & 30 & - & - & - & 14.6 & 62.5 & 22.9 \\
\hline 61 & 30 & 0 & 30 & 30 & 12.5 & 14.6 & 72.9 \\
\hline
\end{tabular}


rate from 48.5 to $100 \%$.

The effect of exposing buds to $61^{\circ} \mathrm{C}$ for 25 to $30 \mathrm{~min}$ raised the production rate of decontaminated cultures to $54.3 \%$ respectively resulting in lower death rate. These results may show that buds were not evenly affected by the temperature treatments since TDP's were not the same as those found in the earlier studies. This may be due to the differences in both physical conditions (e.g. bud sizes, shape and compactness) and physiological conditions (e.g. age, endogenous phenolic release, and past infections with pathogens and insect attacks) of the buds. Some of these differences may have caused deep-seated bud contamination to be protected from the heat treatment. Other buds may have been sensitive or over-exposed to heat, resulting in their death. Also, from these results it is clear that the same time required to kill at $61^{\circ} \mathrm{C}$ was $10 \mathrm{~min}$ longer in bud than in the yeast suspension cultures. Adding anticontaminants in the heat treatment medium (Benomyl, $100 \mathrm{ppm}$, Nystatin, $25 \mathrm{ppm}$ and Carbenicillin $100 \mathrm{ppm}$ ) (Table 5), significantly $(p<0.05)$ improved the proportion of decontaminated cultures $(70.8 \%)$ without any significant change in the bud death rate. None of the Benomyl, Nystatin or Carbenicillin alone had a significant improvement over the decontamination rate of the control.

Exposing buds to two successive heat treatments were less effective than a single heat treatment (Table 6). The initial heat treatment and the period between the two heat treatments had the major influence on the decontamination rate. When the heat treatment of $61^{\circ} \mathrm{C}$ for $30 \mathrm{~min}$ was initially applied, followed by either 52 or $57^{\circ} \mathrm{C}$ for 30 min, 24 hours apart, there was a higher decontamination rate than was obtained with heat treatment of 52 or $57{ }^{\circ} \mathrm{C}$ followed by $61^{\circ} \mathrm{C}$. The best decontamination rate obtained was when the initial heat treatment of buds was $61^{\circ} \mathrm{C}(30 \mathrm{~min})$ followed by $52{ }^{\circ} \mathrm{C}$ (30 min) 24 hrs apart. This decontamination rate (35.4) was significantly $(p<0.05)$ less than the decontamination rate obtained from the single heat treatment at $61^{\circ} \mathrm{C}$ for $30 \min (66.7 \%)$.

Effect of hot water treatment on sets prior to bud excision

Hot water treatment of one-eye sets prior to bud excision at $50{ }^{\circ} \mathrm{C}$ for 60 and 90 min either alone or followed by a hot water treatment at $61^{\circ} \mathrm{C}$ for 30 min, resulted in a maximum decontamination rate of $66.7 \%$ (Table 7). Direct culturing of excised buds from heat-treated sets at $50{ }^{\circ} \mathrm{C}$ for $120 \mathrm{~min}$ gave decontamination rate of $45.8 \%$. A spectacular improvement in the decontamination
Plate 1. Successive steps and treatments of in vitro decontaminated mature bud culture of sugarcane. (A): Greenhouse-grown sugarcane stalks of var NCo 310, (B): waterbath thermal treatment of one-eye sets prior to bud excision, (C): in vitro development of mature bud culture, (D): washed in vitro regenerated plants ready for hardening in greenhouse.
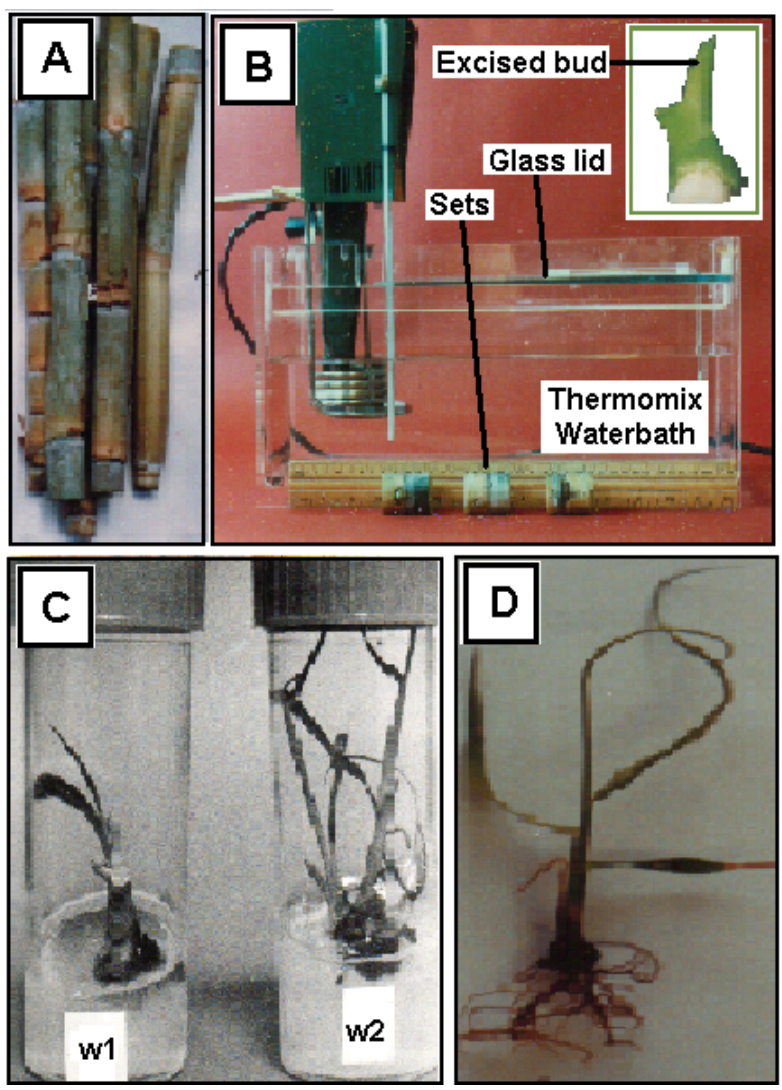

Plates 2. Successful regeneration of sugarcane var NCo 310 plants from in vitro decontaminated mature bud culture. (A): Hardening of plantlets in greenhouse, and (B): mature transplants in greenhouse.

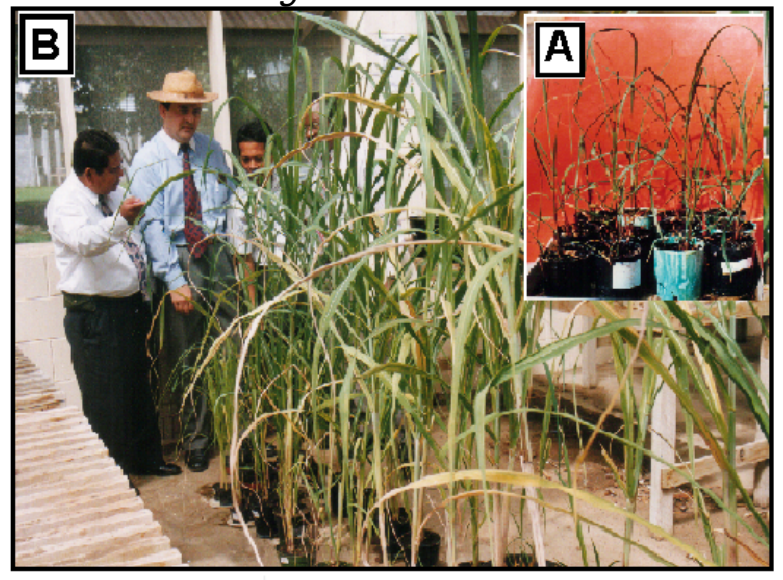


rate to $95.8 \%$ was obtained when the heat treatment $61{ }^{\circ} \mathrm{C}$ for $30 \mathrm{~min}$. the initial hot water treatment of sets seemed to induce a higher tolerance into the buds for the second heat treatment, thus resulting in very low death rates. Plates 1 and 2 summarize the successive steps and treatments of in vitro decontaminated mature bud culture of sugarcane resulting in successful regeneration of plants.

References

1. Ahloowalia BS and Meretzki A (1983) Plant regeneration via somatic embryogenesis in sugarcane. Plant Cell Reports. 2, 21-25.

2. Beezer AE and Sharma PB (1981) On the uptake of Nystatin by Saccharomyces cerevisiae. 1. Basic Considerations. Microbios. 30, 139-151.

3. Dale PJ (1979) The elimination of cocksfoot streak virus, cocksfoot mild mosaic virus and cocksfoot mottle virus from Doctylis glomerata by shoot tip and tiller bud culture. Ann. App. Biol. 93, 285-288.

4. Erwin DC (1973) Systemic fungicide: Disease control, translocation and mode of action. Ann. Rev. Phytopath. 11, 389-422.

5. Hammerschalg RS and Sisler HD (1972) Differential action of Benomyl and Methyl-2benzimidazole carbamate (MBC) in Saccharomyces pastorianus. Pesticide Biochem. Physiol. 2(L), 123-131.

6. Heinz DJ and Mee GWP (1969) Plant differentiation from callus tissue of Saccharum sp. Crop Sci. 9, 346-348.

7. Hendre RR, Mascarenhas AF, Nadgir AL, Pathak M and Jagannathan V (1975) Growth of mosaic virus-virus free sugarcane plants from apical meristems. Indian Phytopath. 28, 175-178.

8. Irvine JE and Benda GTA (1987) Transmission of sugarcane diseases in plant derived by rapid regeneration from diseased leaf tissue. Sugar Cane. 6, 14-16.

9. James DJ and Thurbon IJ (1981) Shoot and root initiation in vitro in apple rootstock M.9 and promotive effects of phlorglucinol. J. Hort. Sci. 56, 15-20.

10. Johnson JA, Perera R and Arditti J (1982) Clonal propagation of Phalaenopsis from flower stalk nodes in anticontaminant containing media. Australian Orchid Review. pp:21-26.

11. Krishnamurthi $M$ and Tiaskal J (1974) Fiji disease resistant Saccharum officinarum var. Pindar subclones from tissue culture. Proc. Int. Soc. Sug. Cane Technol. Plant Breeding section. pp:1-8.
12. Lane WD (1979) In vitro propagation of Spirea bunalda and Prunus cistena from shoot apices. Can. J.Plant.Sci. 59, 1025-1029.

13. Mousa NA (1988) Biochemical genetic studies on some microorganisms. M.Sc. Thesis, University of Alexandria, Egypt.

14. Murashige $T$ and Skoog $F$ (1962) A revised medium for rapid growth and bioassays with tobacco tissue cultures. Physiol. Plant. 15, 473-497.

15. Pollock K, Barfield DG and Shields R (1983) Plant toxicity of antibiotics to plant cell cultures. Plant Cell Reports. 2, 36-39.

16. Roca WM (1980) Annual Repot. Genetic Resources unit, Tissue Culture section. CIAT, Cali. Columbia.

17. Strokes JL (1967) Heat sensitive enzymes and enzymes synthesis in psychrophilic microorganisms. In: Molecular Mechanisms of Temperature Adaptation, (Ed. Prosser CL), pp: 311-323. American Association for the Advancement of Science, Washington, D.C.

18. Wagih, ME, Gordon GH, Ryan CC and Adkins SW (1995). Development of an Auxiliary Bud Culture Technique for Fiji Disease Virus Elimination in Sugarcane. Austr. J. Bot. 43,135-143.

19. Waterworth P and Kahn RP (1978) Thermotherapy and aseptic bud culture of sugarcane to facilitate the exchange of germplasm and passage quarantine. Plant Disease Reporter. 6, 772-772. 